\title{
THE REPRESENTATION OF CULTURE IN ENGLISH TEXTBOOKS PRESCRIBED FOR HIGH SCHOOLS IN INDONESIA
}

\author{
Arnis Silvia \\ Syarif Hidayatullah State Islamic University of Jakarta \\ (arnis@uinjkt.ac.id)
}

Received: $08^{\text {th }}$ March 2015; Revised: $05^{\text {th }}$ April 2015; Accepted: $16^{\text {th }}$ April 2015

\section{ABSTRACT}

This study investigated the culture representation of two prescribed English textbooks suggested by the Indonesian Curriculum and Publishing Centre (Puskurbuk) used in high schools in Indonesia. Its aim was to investigate whether the representation of culture supported the main goal of English as a Foreign Language (EFL) teaching, which is intercultural communicative competence (ICC). For this purpose, culture was classified as source, target, and international target culture (Cortazzi \& Jin, 1990). A classification on the level of ICC was also conducted to these textbooks. It was found that the prescribed English textbooks portrayed the culture of local (Indonesia), the culture of target countries (American and British), and the culture of other international countries in a quantitatively similar portion. However, qualitatively, the presented culture tended to be artificial instead of substantial. Comparison and contrast among cultures were not found, therefore, intercultural competence was not achieved.

Key words: culture representation; English textbooks; intercultural communicative competence

\begin{abstract}
ABSTRAK
Penelitian ini menganalisis pemaparan elemen budaya dalam Buku Bahasa Inggris yang direkomendasikan oleh Puskurbuk untuk sekolah menengah di Indonesia. Penelitian bertujuan untuk mengevaluasi apakah representasi budaya dalam buku ajar bisa mendukung tujuan utama pengajaran bahasa Inggris sebagai bahasa asing, yakni kompetensi komunikasi interkultural (intercultural communicative competence). Penelitian membagi budaya dalam tiga jenis, yaitu source, target, dan international target culture (Cortazzi \& Jin, 1990) serta mengklasifikasikan tingkat kompetensi interkultural yang ditampilkan dalam buku ajar. Hasil penelitian menunjukkan bahwa dalam buku ajar Bahasa Inggris ditampilkan budaya Indonesia, budaya barat (Amerika dan Inggris), dan budaya dari negara lain dalam porsi yang sama besar. Namun, secara kualitatif, budaya yang ditampilkan cenderung berkisar pada aspek artifisial daripada substansial. Representasi budaya tidak memaparkan perbandingan dan perbedaan antara budaya sehingga kompetensi interkultural belum bisa dicapai.
\end{abstract}

Kata kunci: representasi budaya; buku teks Bahasa Inggris; kompetensi komunikasi interkultural

How to Cite: Silvia, A. (2015). The Representation of Culture in English Textbooks Prescribed for High Schools in Indonesia. IJEE (Indonesian Journal Of English Education), 2(1), 1-16. doi:10.15408/ijee.v2i1.1432

Permalink/DOI: http://dx.doi.org/10.15408/ijee.v2i1.1432 


\section{INTRODUCTION}

Since the goal of EFL teaching is the intercultural communicative competence, "learning a foreign language becomes a kind of enculturation, where one acquires new cultural frames of reference and a new world view, reflecting those of the target language culture and its speakers" (Alptekin, 2002, p. 58). In this context, EFL materials should contain not only the target culture, but also the the other cultures (i.e. source culture or local culture and the international target culture). The cultural representation does not limit to the names of traditional arts, for instance, but also to the intercultural information to the EFL users (students). In this case, culture can be represented by its products (tangible objects), persons (figures or famous people), practices (ceremonies, life style, et cetera.), or perspectives (way of thinking, stereotypes).

While EFL textbooks are generally expected to contain elements of target culture where English is introduced, a large number of studies suggest that target language is not always presented and the information in language textbooks is generally fragmented and highly generalized, indicating only the norms of behavior (Aliakbari, 2012).
Culture, by its nature, cannot be separated from language as language expresses, embodies and symbolizes cultural reality. Language determines thoughts and culture; language influences thought and culture; culture influences people's language; and language and culture influence each other (Wardhaugh, 2002, p. 219-220). Mitchell and Myles (2004, p. 235) supported this notion as 'language and culture are not separate, but are acquired together, with each providing support for the development of the other. Therefore, it is unavoidable that 'the person who learns language without learning culture risks becoming a fluent fool' (Bennet, Bennet \& Allen, 2003, p. 237). Therefore, foreign language should employ an integrative view of both language, text, discourse and (the rest of) culture and society (Risager, 2005).

As language and culture are not two different teaching subjects, foreign language learning is at the same time cultural learning. Kramsch (1993, p. 1) emphasized that 'culture in language learning is always in the background in classrooms when language learners are looking for a good communicative competence and challenging their ability to make sense of the world around them.' Further, Adaskou, Britten and Fahsi (1990, p. 3-10) 
mentioned four senses of culture that language teaching may involve several senses as described in the following.

\section{The Aesthetic Sense}

Aesthetic sense relates to the socalled 'big $C^{\prime}$ which means the culture that commonly becomes the main reasons for language teaching/ learning, including the media, the cinema, music (either serious or popular) and literature.

\section{The Sociological Sense}

Sociological sense includes culture with 'small $c$ ' such as the organization of a family, a home life, interpersonal relations, material conditions, work and leisure, customs and institutions. Culture in this term is a vast area, which only some parts can ever be selected by the learners.

\section{The Semantic Sense}

Semantic sense associates with the concepts, perceptions, or thought towards the culture.

\section{The Pragmatic Sense}

Pragmatics sense deals with the background knowledge, social and paralinguistic skills and language code, which are necessary for successful communication,
including:

the ability to use appropriate exponents of the various communicative functions; the ability to use appropriate intonation patterns; the ability to conform to norms of politeness, where different from the learners' culture, including taboo avoidance; awareness of conventions governing interpersonal relations questions of status, obligation, license, where different from the learners' culture; andfamiliarity with the main rhetorical conventions in different written genres, e.g. different types of letters and messages, form-filling, advertisements.

Later, Yuen (2011) mentions some cultural components in four Ps namely "products, practices, perspectives, and persons". Products refer to tangible culture objects, such as: movies, TV programs, food, merchandise, prints, travel destinations, etc. Practices relate to customs, daily life, sports, school life, and celebrations. Perspectives are about inspirations, values, myths, world views, beliefs, etc. Lastly, persons are about famous individuals (fictitious or real), figures, characters, etc. The four senses are employed in this study to classify the culture presented in the 
investigated textbooks. Additionally, the four $P_{S}$ are used to explain the cultural components the textbooks contain.

Concerning the representation of culture in English textbook, according to Cortazzi and Jin'sclassification (1990), EFL materials could be analyzed in terms of source cultures, target culture, and international target culture. These three categories of culture suggest that EFL materials can load three types of information. First, source culture materials refer to the materials which present language learners' own culture, such as textbooks produced at national level. Second, target culture materials usually focus on the culture of United Kingdom or United States. Third, international target culture materials involve the culture of English speaking countries where English is their international language, such as some African countries, some Asian countries, and European countries.

Beside containing information on source culture, target culture, and international target culture, EFL materials also contain four elements of culture i.e. products, persons, practices and perspectives. In the EFL materials, products are indicated by some form like pictures, illustration or realia, which show tangible cultural objects like foods, movies, songs, news or fashion. Here is an example of an EFL material section that contains products of culture. The second element, persons, refers to figures, publicists, and other famous people either real or fictitious, which are included in the culture. It could be popular artists, movie actors, pop singers, characters in a movie, comedians, et cetera. The third element of culture, practices, refers to the real life activities, which are inherited to a particular group of community and passed from generation to generation. Lastly, the fourth element of culture, perspectives, reflect the way of certain group of people see some aspects of life, like family relationships, friendships, concepts about money, time, and so on.

Additionally, there are also senses of culture that can be carried out by EFL materials, namely aesthetic sense, sociological sense, semantic sense, and pragmatic sense. Aesthetic sense of culture in EFL materials refers to elements of products and persons, which usually attract the learners' two senses (hearing and sought). This sense is usually presented in the forms of movies, TV programs, pop songs, novels, comics, and so on. Secondly, sociological sense in EFL materials commonly expresses about family life, work and leisure, neighborhood, and such. Thirdly, semantic sense of culture reflects the concepts, perceptions, or 
thought towards culture. This can be in the forms of opinion, general belief, norms, and such. Lastly, pragmatic sense of culture covers background knowledge, paralinguistic skill, social skill and conventions. In EFL materials, this sense is usually presented in the forms of intonation patterns, norms of politeness, writing conventions in various forms, and notes on taboo avoidance.

The abovementioned types of culture (source culture, target culture and international target culture), elements of culture (products, persons, practices, perspectives), and senses of culture (aesthetic, sociological, semantics, pragmatics) are conveyed by so-called cultural information. This information takes some forms, such as 1) informative texts, 2) texts presenting foreign attitudes and opinions, 3) dialogues about everyday life, 4) contextualized writing tasks, 5) idioms and collocations, 6) realia, 7) visual illustrations, or sound recordings (Adaskou, Britten \& Fahsi, 1990, p. 5).
Moving to intercultural communicative competence, Byram (as cited in Baker, 2012, p. 66) defined intercultural awareness as "a conscious understanding of the role culturally based forms, practices, and frames of understanding can have in intercultural communication, and an ability to put these conceptions into practices in a flexible and context specific manner in real time communication". Savignon (as cited in Xiao, 2010) called this as intercultural communicative competence (ICC), which refers to the complex ability needed to perform effectively and appropriately when interacting with others who are linguistically and culturally different from oneself. This intercultural communicative competence is developed through some stages namely basic cultural awareness, advanced cultural awareness, and intercultural awareness. To better comprehend these features of intercultural awareness, each stage is presented below.

Table 1. Level of Intercultural Competence

(Byram, as cited in Baker, 2012, p. 66)

\begin{tabular}{ll}
\hline Level & Description \\
\hline Level 1 & An awareness of: \\
basic cultural awareness & $\begin{array}{l}\text { 1. culture as a set of shared behaviours, beliefs, and values; } \\
\text { 2. the role culture and context play in any interpretation of }\end{array}$ \\
& $\begin{array}{l}\text { meaning; } \\
\text { 3. our own culturally induced behaviours, values, and beliefs and } \\
\text { the ability to articulate them; }\end{array}$ \\
\hline
\end{tabular}




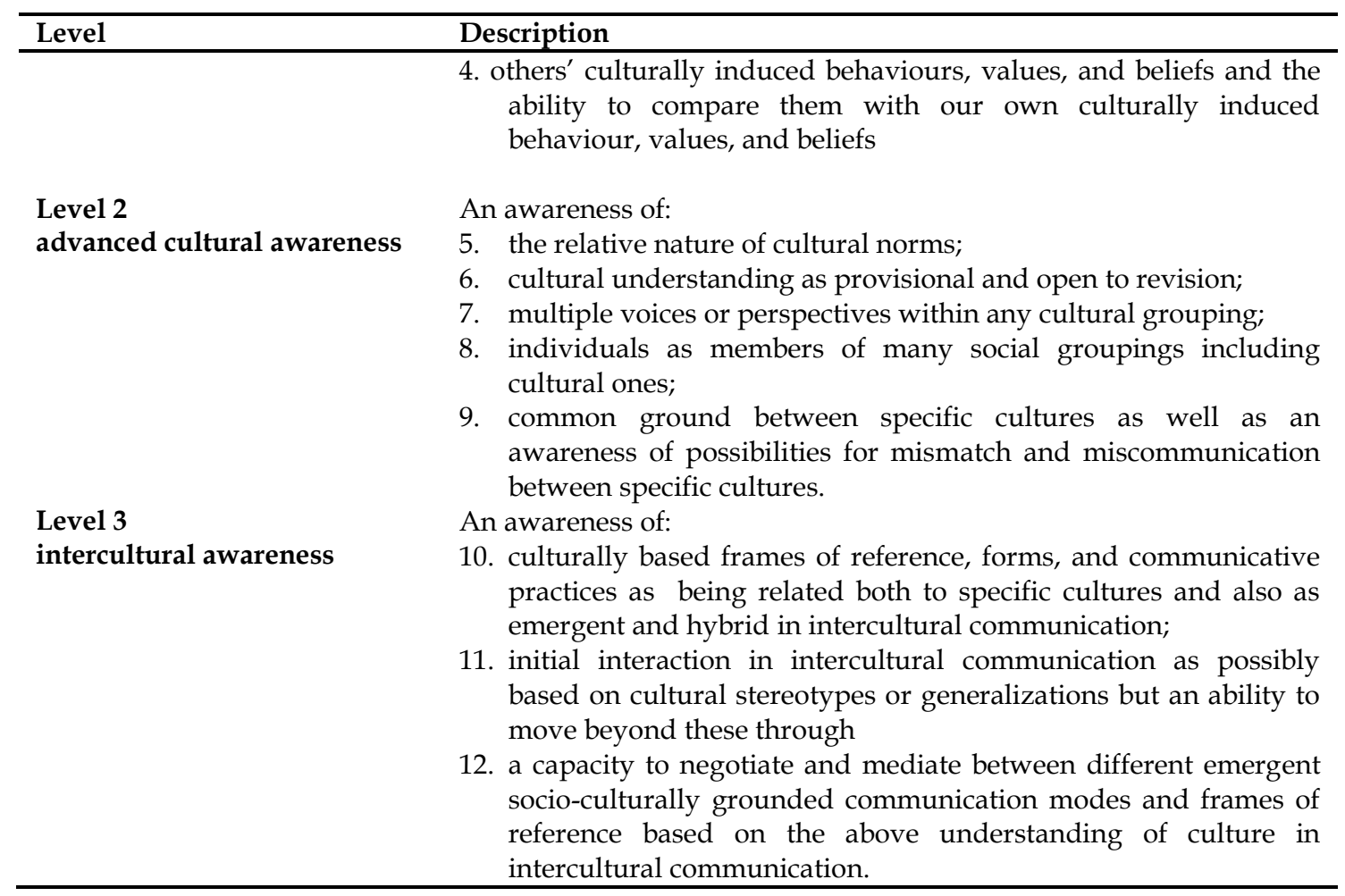

The present study aimed at examining to what extent the representation of culture in English textbooks prescribed for High Schools in Indonesia support the students' intercultural communicative competence. The concept of culture and its role in EFL teaching was firstly reviewed. Then, the content of culture in the two series of English textbooks was analyzed, and the implication of the representation was discussed.

\section{METHOD}

To obtain the textbook titles, a survey was conducted to fourty two madrasahs in DKI Jakarta region. By convenient sampling, twenty six responses were recorded and the English textbooks used by these schools are presented as follows.

Table 2.English Textbooks in MTS

Negeri in DKI Jakarta (preliminary survey)

\begin{tabular}{lcc}
\hline \multicolumn{1}{c}{ Title } & Year & Frequency \\
\hline English in Focus & 2008 & 11 \\
English on Sky & 2007 & 8 \\
Scaffolding & 2008 & 5 \\
Real Time & 2008 & 3 \\
Flying Start & 2007 & 3 \\
Contextual Teaching and & 2007 & 1 \\
Learning & & \\
\hline
\end{tabular}


Two titles of English textbook namely English in Focus and English on Sky were then chosen as the objects of analysis. These books are written by Indonesian authors and consist of three books in each series, Book 1 for grade VII, Book 2 for grade VIII, and Book 3 for grade IX. English in Focus was the prescribed English textbooks published by the government (Puskurbuk), while the English on Sky was published by a commercial publisher. Both books claimed that they comply with the current curriculum and using communicative approach. The data related to culture representation are taken from descriptive texts, dialogue scripts, idioms, visual illustrations (photographs, drawings, and sketches), audio recordings, or realia. These data are then categorized into checklists, as described in the following, which details are provided in the appendices.

1) Checklist A: Types of cultural information (using Adaskou, Britten and Fahsi's Framework).

2) Checklist B: Types of culture (using Cortazzi and Jin's framework).

3) Checklist C: Senses of culture (Adaskou, Britten and Fahsi's Framework).

4) Checklist D: Elements of culture (Yuen's framework).

5) Checklist E: Level of Intercultural Competence (Byram's framework).
Textbooks are classified as containing culture when they mention about particular culture in the form of products, persons, practices, and perspectives. A mere mention of "Eiffel tower", for instance, is an input for "international target culture" under the category of "products". A mention of "Bruno Mars" is an input for "target culture" under the category of "persons", and so on.

\section{FINDINGS AND DISCUSSION}

Types of Cultural Information

The following sub-section describes the frequency of each type of cultural information in the two selected books, i.e. English on Sky (EOS) and English in Focus (EIF).

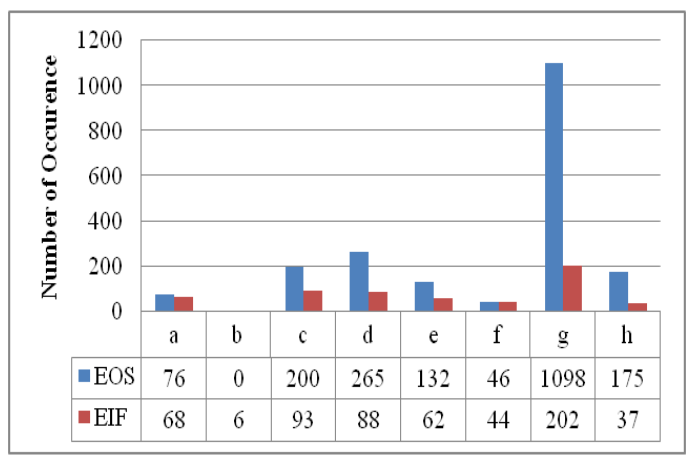

Chart 1.Types of Cultural Information in Both Books

Furthermore, the cultural information is analyzed according to the types of texts or tasks in the text as described in Chart 1. As seen in this 
chart, the alphabetical order of " $\mathrm{a}-\mathrm{h}$ " represents a) informative text, b) texts presenting foreign attitudes and opinions, c) dialogues about daily life, d) contextualized writing tasks, e) idioms and collocations, f) realia or pseudo realia, g) visual illustration, and h) sound recording.

Visual illustrations make the highest frequency compared to dialogues, texts, and sound recordings. Whereas other media containing social sense of culture such as dialogues about daily life, idioms and collocations, and texts presenting other cultures are not presented. The visual illustration presents both "products" and "persons" elements.

One surprising finding is that there is only a small number of occurrences of descriptive texts depicting cultures (source culture, target culture, or international target culture). On the other hand, information in descriptive texts is potentially rich in presenting cultures. When discussing about school, for instance, a descriptive text about school holidays in London, Los Angeles, and Tokyo are good resources for intercultural information. Additionally, when discussing about animals, some descriptive texts about festivals in Madura (Karapan Sapi) and Bull Race in Spain are also culturally rich in facilitating

the

intercultural information.

Above all, the types of cultural information in both books (except songs and pictures) are less explicit in referring to cultures. This issue is in line with Hatoss (2004, p. 27) who argue that 'a common problem in language textbooks is that learners are expected to pick up the cultural differences automatically without any conscious effort on the part of teachers to encourage them to reflect on the cultural knowledge, and without raising their awareness of their own culture'. In line with this, McKay (2002) adds that teaching materials should be designed with the aim of encouraging the students to reflect their own culture in relation to others, thus helping them to establish a sense of intercultural communication (2002). It implies that the cultural information should catch the learners' attention. Giving specific section is an instance. By putting the cultural values in separated and explicit sections such as "Cultural Note", "Do you know?", "New Horizon", “Culture Point" and so on, it raises the learners' cultural awareness - of their own culture and others. Thus, in the "Cultural Note", if there are any suggestions of comparing the way people address others by calling their first name or last name, for instance, it 
would be a very good opportunity to improve the learners' ability to reflect on both target culture and source culture.

What can be inferred from these types of cultural information is that, there are a lot more media that need to be explored to introduce culture, such as idioms and collocations, texts presenting foreign attitudes, realia, authentic materials (newspaper, novel excerpt, and movie script excerpts), and authentic pictures (instead of illustrated ones).

\section{Types of Culture}

The overall occurrence of cultural information suggests a balance presentation amongst culture. Relatively, source culture is the most prominently presented in the textbooks, followed by target culture, culture-free, and international target culture materials.

The prominent presence of source culture is similar to English textbooks studied by Abdullah \& Chandran (2009) in Malaysia, Rajabi \& Ketabi (2012) in Iran, Mahmood, Asghar \& Husein in Pakistan (2012) and also Adaskou, Britten \& Fahsi (1990) in Morocco. This research is also similar to Abdullah \& Chandran's study in term of local references that often appeared in English textbooks. The presentation of local culture helps the learners to activate their local knowledge, i.e. familiarity with customs and preoccupations of their community (Widdowson, 1998; Munandar \& Ulwiyah, 2012). This means that language learners can raise their own cultural awareness while learning the target language (Kilickaya, 2013).

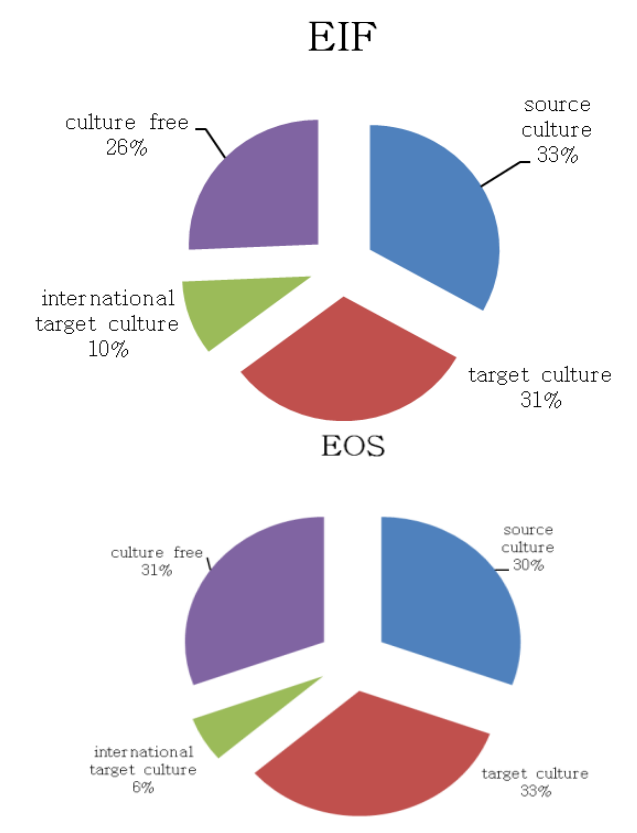

Chart 2. Types of Cultures in Textbooks

However, the presentation of this culture tends to be "surface culture" instead of "deep culture". This is in accordance with Paige, et. al (as cited in Yuen, 2011), in their review of the literature on culture learning in language education, which note that 
language textbooks often represent cultures by taking a 'tourist's perspective', that focuses on topics such as 'food' and 'transport'. Referring to the aforementioned four aspects of culture, they could be categorized as the products and the practices.

According to Paige et al (as cited in Yuen, 2011), the information in language textbooks is generally fragmented and highly generalized, indicating only the norms of behavior. Without actual experience of the culture or being alerted to individual differences, textbook users may assume that the information about, for example, the way some individuals behave, applies to the culture as a whole, which easily gives rise to prejudice or stereotype. Consequently, textbooks' cultural presentation less supports selfawareness and self-understanding towards local culture, and understanding on the values of other cultures.

\section{Senses of Culture}

In terms of the senses of culture, aesthetic sense appears most frequently on both textbooks. Arts, pop culture, buildings, and food are some of the theme. Sociological sense appears less than aesthetic sense, which focuses on the source culture (Indonesian culture). Pragmatic sense is also presented explicitly as the grammar section, pronunciation section, vocabulary section, and speech act sections. Pragmatic sense only appears in target culture. Lastly, there is no presence (at least, explicitly) of semantic sense in both textbooks.

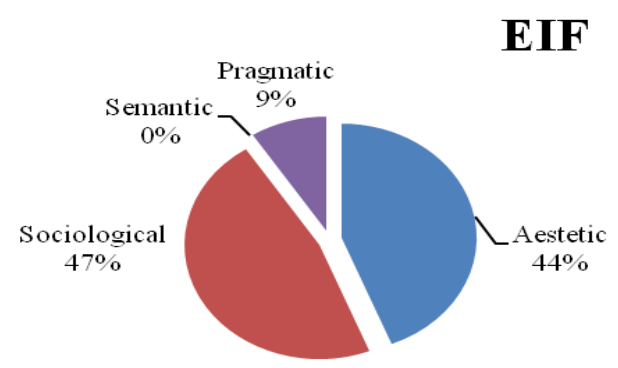

EOS

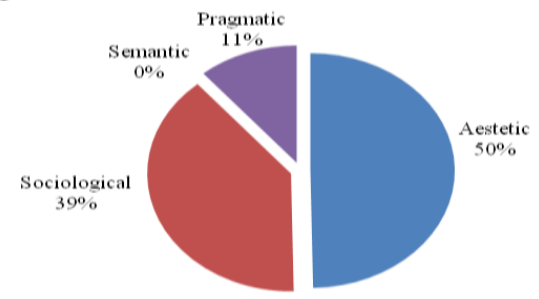

Chart 3. Senses of Culture in the Textbooks

The predominant appearance of aesthetic sense in this study is inconsistent with the findings of Hermawan \& Nurkhasana (2012) and Abdullah \& Chandran (2012), which report that sociological sense is the most prominent dimension of cultural content in the textbooks.

On the other hand, semantic sense that deals with perceptions and thought processes, which differentiate between 
one culture to the others is not presented in the textbooks. For instance, there is no information about how native speakers think about giving present to their teachers. In addition, there is no explicit section describing this semantic sense in both books. According to Corbett (2003), learners may not want to adopt the practices or beliefs of the target culture, but they should be able to understand them if they want to achieve a high proficiency in the target language.

\section{Elements of Culture}
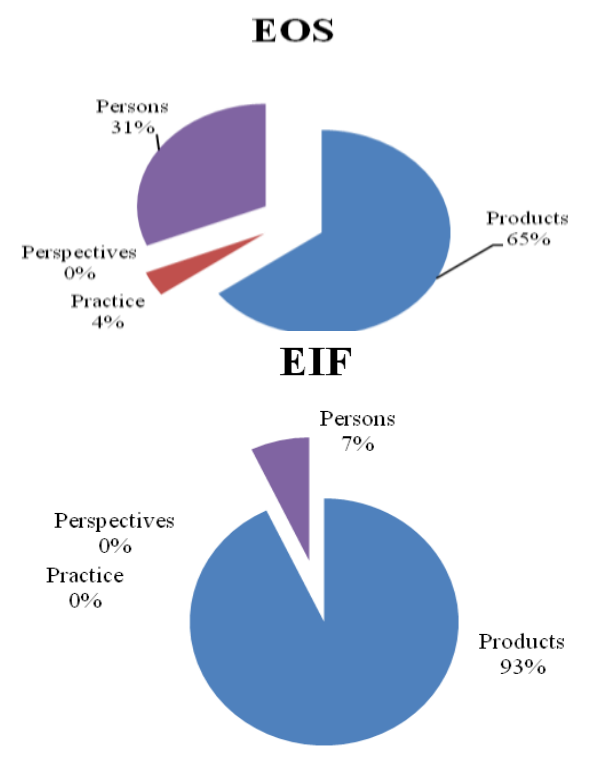

Chart 4. Elements of Culture in English Textbooks

Chart 4 describes the elements of culture, from which it is clearly seen that products are dominant in almost the whole culture presentation in English in Focus series (93\%). Similarly, products also has the highest percentage, which accounts to $65 \%$ of the whole cultural presentation in English on Sky series.

This findings imply that culture is mainly shown by products instead of practices and perspectives. Products are shown by foods (sandwich, sushi, kebab); landmarks (Spinx, Borobudur, Merlion Statue, Great Wall); arts and crafts (woodcraft, batik, sculpture); dances (tari piring, tari janger, tari jaipong). Practices are shown by target culture celebrations (Halloween, Valentine Day, Suprise Party, Baby Shower). Lastly, persons are shown by famous figures of source culture, target culture and international target culture (Krisdayanti, Nidji, Thomas Alva Edison, Pasteur). Perspective is not presented explicitly in both books.

This dominant presence of product element is in line with Kramsch's survey showing that in many language classes, culture was frequently reduced to "the four Fs", which means "foods, fairs, folklores and statistic facts" (Kramch, 1993, p. 218). Similarly, it also supports Yuen (2011)'s study which shows that products relating to entertainment appear most frequently, followed by practices (celebrations like Halloween, 
Thanksgiving, Sapporo Festival), textbooks, it can be concluded that the perspectives (presented in myths, intercultural competence is on level 1 stories, folklores), and lastly persons (the lowest level). Though the (Au Sung Kyii and Stephen Hawking).

\section{Level of Intercultural Communicative Competence}

By looking at the types of culture, elements of culture, and senses of culture presented in the two English researcher decides that the intercultural competence is in level 1 , the real presentation on the textbooks do not comply all the criteria mentioned by Byram in level 1 (basic cultural awareness). The results of textbook analysis is summarized in Table 1.

Table 2. The Level of Intercultural Competence of the Textbooks

\begin{tabular}{|c|c|c|}
\hline $\begin{array}{c}\text { Criteria of basic cultural awareness } \\
\text { (level 1) }\end{array}$ & $\begin{array}{l}\text { Status of the } \\
\text { textbooks under } \\
\text { study }\end{array}$ & Note \\
\hline $\begin{array}{l}\text { 1. culture as a set of shared } \\
\text { behaviours, beliefs, and } \\
\text { values; }\end{array}$ & Not mentioned & $\begin{array}{l}\text { There is no comparisons among culture } \\
\text { and there is no information about } \\
\text { culture-related behaviors, beliefs, and } \\
\text { values (which is explisit and noticable } \\
\text { for the students) }\end{array}$ \\
\hline $\begin{array}{l}\text { 2. the role culture and } \\
\text { context play in any } \\
\text { interpretation of meaning; }\end{array}$ & Mentioned & $\begin{array}{l}\text { There are some texts about family life } \\
\text { and jobs in target culture which is } \\
\text { different from source culture }\end{array}$ \\
\hline $\begin{array}{l}\text { 3. our own culturally } \\
\text { induced behaviour, } \\
\text { values, and beliefs and the } \\
\text { ability to articulate this; }\end{array}$ & Mentioned & $\begin{array}{l}\text { This is mentioned in the form of } \\
\text { contextualized writing task (writing a } \\
\text { letter/ email to a pen pal in Melbourne) }\end{array}$ \\
\hline $\begin{array}{l}\text { others' culturally induced } \\
\text { behaviour, values, and } \\
\text { beliefs and the ability to } \\
\text { compare this with our own } \\
\text { culturally induced } \\
\text { behaviour, values, and } \\
\text { beliefs. }\end{array}$ & Not mentioned & $\begin{array}{l}\text { There is no information nor } \\
\text { comparisons and contrast among } \\
\text { cultures. }\end{array}$ \\
\hline
\end{tabular}

From the table above, it can be inferred that intercultural competence should be more facilitated by 1) promoting behaviors, values, and beliefs of different cultures. 2) describing own culture to other speakers, 3) promoting the awareness on the similarities and difference among cultures.

\section{CONCLUSION AND SUGGESTION}

The study has found that the English textbooks portray cultures mainly in the form of visual 
illustrations, thus cultures are represented mostly by their products and persons. On the other hands, other media of cultural representation, such as descriptive texts, idioms, collocation, and texts presenting foreign opinions which contain more practices and perspectives are minimally found.

Subsequently, source culture, target culture and international target culture are found in a balance proportion where source culture is more dominant than target culture and international target culture. This finding supports Kramch \& Sullivan (1996) and Alptekin (2002)'s theories that the EFL pedagogy should prepare learners to be both global and local speakers of English.

Later on, the study also points out that the textbooks represent more "surface culture" compared to "deep culture". Aesthetic sense and pragmatic sense are presented more frequently than sociological sense and semantic sense. Cultures are mainly represented by people names, food, landmarks, dances (products) and language forms (expressions of showing sympathy, asking for opinion, et cetera). On the contrary, values, opinions, and perspectives among cultures are not represented.

Lastly, the study concludes that the examined textbooks do not support intercultural

communicative competence as the cultural content is at the level 1 of Byram's classification (basic cultural awareness). It implies that the textbooks provide the various existence of culture which enable the learners to be aware other culture than theirs. Level 1 also means that comparison and contrast among cultures are not found, therefore intercultural competence is not facilitated.

Concerning the suggestions, the imbalance selection of English textbooks should be addressed by all relevant parties, which include the centre of curriculum and publishing (Puskurbuk), Board of National Standard for Education (BSNP), publishers, authors, and teachers. In this case, BSNP and Puskurbuk have a major role in socializing the standard of criteria for English textbooks to the publishers and the prospective authors. At the same time, BSNP and Puskurbuk should select the authors of English textbooks based on their experience in curriculum and material development, cross-cultural understanding, and publishing records. This is aimed at producing high quality English textbooks for Indonesian schools.

As the users in the classroom, English teachers should be aware of cultural knowledge, which needs to be 
addressed beside the English teaching materials such as grammar and reading text. Equipping themselves with information of other cultures (gained from the magazine, newspapers, TV programs, or internet) is a good solution in balancing the artificial culture representation in the textbooks, which lead to stereotypes. If possible, teachers can provide video reports about the practices or perspectives of other countries' culture taken from educational websites (such as KangGuru, National Geographic Channel, History Channel, et cetera.)

\section{REFERENCES}

Abdullah, N., \& Chandran, S.K. (2012). Cultural Elements in a Malaysian English Language Textbook retrieved from ddms.usim.edu.my/handle/1234 $56789 / 713$.

Adaskou, K, et al. (2002). Design Decisions on the Cultural Content of a Secondary English Course for Morocco in ELT Journal Volume $44 / 1,3-10$.

Alptekin, C. (2002). Towards Intercultural Communicative Competence in ELT. ELT Journal Volume 56/1, 67-64.

Aliakbari, M. (2004). The Place of Culture in the Iranian ELT
Textbooks in High School Level. PAAL Japan 17th Conference Proceedings, 1-14. Retrieved from http://www.paaljapan.org/resou rces/proceedings/2004/Aliakbari .pdf.

Badan Standar Nasional Pendidikan (BSNP). (2006). Panduan Penyusunan Kurikulum Tingkat Satuan Pendidikan Jenjang Pendidikan Dasar dan Menengah. Retrieved from http://bsnpindonesia.org/id/wpcontent/uploads/kompetensi/Pa nduan_Umum_KTSP.pdf.

Badan Standar Nasional Pendidikan (BSNP). (2011). Instrumen Penilaian Buku Teks Bahasa Inggris Tingkat SMP/MTs Tahun 2011. Retrieved from http://bsnpindonesia.org/id/?p=734.

Baker, W. (2012). From Cultural Awareness to Intercultural Awareness: Culture in ELT. ELT Journal Volume 66/1, 62 - 70.

Bennett, J., Bennett, M., \& Allen, W. (2003). Developing intercultural competence in the language classroom. USA: Information Age Publishing.

Byram, M., Gribkova, B., \& Starkey, H. (2002). Developing the intercultural dimension in language teaching: a 
practical introduction for teachers Strasbourg: Council of Europe.

Byram, M. (1993). Language and Culture Learning: The Need for Integration in Byram, Michael (ed.) Germany, Its Representation in Textbooks for Teaching German in Great Britain. Frankfurt am Main: Diestered.

Byram, M. (1989).Cultural Studies in Foreign Language Education. Clevedon, UK: Multilingual Matters.

Canale, M. (1980). Theoretical Bases of Communicative Approaches to Second Language Teaching and Testing. Applied Linguistics, 1, 135.

Cortazzi, M., \& Jin, L. (1999). Cultural Mirrors, Materials and Method in the EFL Classroom in Hinkel, Culture in Second Language Teaching and Learning Cambridge: Cambridge University Press.

Hinkel, E. (2005). Culture in Second Language Teaching and Learning. Shanghai: Shanghai Foreign Language Education Press.

Kramsch, C., \& Sullivan, P. (1996). Appropriate pedagogy. ELT Journal Volume 50/3, 199-212.
Kramsch, C. (1993). Context and Culture in Language Teaching. London: Oxford University Press.

Liddicoat, A.J. (2002). Static and Dynamic Views of Culture and Intercultural Language Acquisition. Babel, v.36, no.3, 4-11.

Liddicoat, A.J., et al. (2003). Report on intercultural language learning. Canberra ACT: Commonwealth of Australia.

Lund, R. (2006). Questions of Culture and Context in English Language Textbooks: A Study of Textbooks for the Teaching of English in Norway. A Dissertation in Universitet I Bergen 1 - 350.

McKay, S.L. (2004). Western Culture and the Teaching of English as an International Language. English Teaching Forum. 42,2, 10-15.

McKay, S.L. (2002). Teaching English as an International Language: Rethinking Goals and Approaches. Oxford: Oxford University Press.

Mitchell, R., \& Myles, F. (2004). Second Language Learning Theories $2^{\text {nd }}$ edition. London: Arnold.

Munandar, M.I., \& and Ulwiyah, I. (2012). Intercultural Approaches to the Cultural Content of Indonesia's High School ELT Textbooks. CS Canada Cross- 
Cultural Communication Vol. 8, No. 5, 67-73.

Rajabi, S., \&Ketabi, S. (2012). Aspects of Cultural Elements in Prominent English Textbooks for EFL Setting.Theory and Practice in Language Studies, Vol. 2, No. 4, 705712.

Risager, K. (2007). Language and Culture Pedagogy. Clevedon: Multilingual Matters.

Rohmah, Z. (2009). EFL Materials in Madrasah Tsanawiyah: What Do They Really Need?. TEFLIN Journal, Volume 20, Number 1,104117.

Shannon, P. (2010). Textbook Development and Selection. International Encyclopedia of Education (third edition), 397-402.

Tomlinson, B. (2005). The Future for ELT Materials in Asia. Electronic Journal of Foreign Language Teaching, Vol. 2, No. 2, 5-13.

Wardhaugh, R. (2002). An Introduction to Sociolinguistics 4th Edition. Sussex: Wiley-Blackwell Publishing.

Widdowson, H.G. (1998). Context, Community, and Authentic Language. TESOL QUARTERLY Vol 32, No. 4, 705-716.
Yuen, K.M. (2011). The Representation of Foreign Cultures in English textbooks. ELT Journal Advance Access, March 2011, 1-9.

Zakaria \& Hashim. (2010). Local Cultural Aspects in the KBSM English Language Materials. Universiti Teknologi Malaysia Journal, 2010, 1-10.

\section{Cited English Textbooks}

Bates, N. (2007). Real Time. Jakarta: Erlangga.

------ (2009). Contemporary College English for Listening. China: Foreign Languge Teaching and Research Press.

Richards, J.C., Hull, J. \& Proctor, S. (2010) Interchange (series). Cambridge: Cambridge University Press.

Liz \&Soars, J. (2010). Headway. Oxford: Oxford University Press.

Mukarto, et.al. (2002). English on Sky1. Jakarta: Erlangga.

Wardiman, A., Jahur, M., \&Djusma, M. (2008). English in Focus. Jakarta: Puskurbuk. 